JIKAP PGSD: Jurnal Ilmiah Ilmu Kependidikan

Vol,3. No,3. Tahun 2019

e-ISSN: 2597-4440 dan p-ISSN: 2597-4424

(c) (1) This work is licensed under a Creative Commons Attribution

4.0 International License

\title{
Pengembangan Media Pembelajaran Berbasis Aplikasi Lectora Inspire Pada Mata Pelajaran IPS Kelas V Di SDN 197 Sapolohe Kecamatan Bontobahari Kabupaten Bulukumba
}

\author{
Ahmad Syawaluddin', Andi Makkasau ${ }^{2}$, Ina Fitrayani Jamal ${ }^{3}$ \\ ${ }^{123}$ PGSD FIP Universitas Negeri Makassar \\ Email: ${ }^{1}$ unmsyawal@unm.ac.id \\ 2andim8341@gmail.com \\ 3m4.2inafitrayanijamal@gmail.com
}

\begin{abstract}
Abstrak. Penelitian ini menelaah tentang pengembangan media pembelajaran berbasis aplikasi lectora inspire pada mata pelajaran IPS Kelas V di SDN 197 Sapolohe, Kecamatan Bontobahari, Kabupaten Bulukumba. Tujuan penelitian yaitu untuk mendeskripsikan (1) gambaran awal kebutuhan media pembelajaran berbasis aplikasi lectora inspire pada mata pelajaran IPS Kelas V; (2) gambaran hasil pengembangan media pembelajaran berbasis aplikasi lectora inspire pada mata pelajaran IPS Kelas V, dan (3) tingkat kelayakan media pembelajaran berbasis aplikasi lectora inspire pada mata pelajaran IPS Kelas V di SDN 197 Sapolohe Kecamatan Bontobahari, Kabupaten Bulukumba. Pendekatan penelitian ini adalah penelitian dan pengembangan (research and development), dengan model pengembangan borg \& gall. Proses pengembangan media pembelajaran berbasis aplikasi Lectora Inspire pada mata pelajaran IPS melalui 8 tahap, yaitu Penelitian pendahuluan dan pengumpulan data, Perencanaan, Pengembangan produk, Uji validitas (uji ahli), Revisi I, Uji kelompok kecil, Revisi II, dan Produk akhir.Teknik pengumpulan data menggunakan instrumen angket. Analisis data yang digunakan yaitu analisis data deskriptif kuantitatif. Tingkat kelayakan media pembelajaran berbasis aplikasi Lectora Inspire pada mata pelajaran IPS berdasarkan penilaian ahli materi sebesar 4,35, ahli media sebesar 3,8, praktisi pembelajaran (guru) sebesar 4,55 dan siswa sebesar 4,54 sehingga memperoleh rerata skor sebesar 4,31 dengan kategori sangat baik yang menunjukkan hasil bahwa media pembelajaran tersebut layak untuk digunakan dalam proses pembelajaran bagi siswa Kelas V SDN 197 Sapolohe, Kecamatan Bontobahari, Kabupaten Bulukumba.
\end{abstract}

Kata kunci: Media Pembelajaran, Aplikasi Lectora Inspire.

Abstract. This study studies on the development of media-based learning applications Lectora inspire on class V IPS courses at SDN 197 Sapolohe, Bontobahari Sub-district, Bulukumba district. The purpose of the research is to describe (1) The initial overview of the media needs of the application-based Lectora inspire in IPS class V subjects; (2) Overview of the results of the development of media-based learning application Lectora inspire on the subject of IPS class V, and (3) the level of media feasibility learning application-based Lectora inspire on the subjects of IPS class V at SDN 197 Sapolohe subdistrict Bontobahari, Bulukumba regency. This research approach is research and 
JIKAP PGSD: Jurnal Ilmiah Ilmu Kependidikan

development, with the Borg \& Gall development model. The process of development of media-based learning application Lectora Inspire on IPS subjects through 8 stages, namely research introduction and data collection, planning, product development, validity test (expert test), revision I, test small group, Revision II, and final product. Data collection techniques using poll instruments. Analysis of the data used is quantitative descriptive data analysis. The level of media feasibility learning application Lectora Inspire on IPS subjects based on a material expert assessment of 4.35 , a media expert of 3.8, a teaching practitioner (teacher) of 4.55 and a student of 4.54 that gained an average A score of 4.31 with a very good category that shows the results that the learning media is worthy to be used in the learning process for students of class V SDN 197 Sapolohe, Bontobahari Sub-district, Bulukumba Regency.

Keywords: learning Media, Application Lectora Inspire.

\section{PENDAHULUAN}

Pendidikan adalah bagian terpenting dalam kehidupan manusia. Pendidikan menjadi aspek utama terciptanya sumber daya manusia yang berkualitas. Kualitas pendidikan sangat ditentukan oleh keberhasilan proses pembelajaran. Dalam sistem pendidikan, proses belajar tidak hanya dilakukan oleh peserta didik secara individu, tetapi ada beberapa komponen yang terlibat dan saling mempengaruhi, antara lain pendidik atau guru, media dan strategi pembelajaran, kurikulum, serta sumber belajar (Khanifatul, 2013).

Menurut Prastowo (2011) kompetensikompetensi inti yang wajib dimiliki seorang guru diantaranya adalah mengembangkan kurikulum yang terkait dengan bidang pengembangan yang diampu, menyelenggarakan kegiatan pengembangan yang mendidik, mengembangkan materi pembelajaran yang diampu secara kreatif dan memanfaatkan teknologi informasi dan komunikasi untuk berkomunikasi dan mengembangkan diri. Dari tuntutan-tuntutan sekaligus kewajiban-kewajiban ini, guru dituntut mampu menyusun bahan ajar atau media pembelajaran yang inovatif, misal menyusun bahan ajar cetak, model/maket, bahan ajar audio, bahan ajar audiovisual, ataupun bahan ajar interaktif.

Pendidikan Ilmu Pengetahuan Sosial (IPS) di Indonesia tidak dapat dipisahkan dari dokumen kurikulum yang memuat IPS sebagai mata pelajaran untuk pendidikan di sekolah dasar dan menengah. Ilmu sosial adalah semua bidang ilmu yang berkenaan dengan manusia dalam konteks sosial atau dengan kata lain adalah semua bidang ilmu yang mempelajari manusia dengan masyarakat atau lingkungannya. Pembelajaran merupakan bantuan yang diberikan pendidik agar dapat terjadi proses perolehan ilmu dan pengetahuan, penguasaan kemahiran dan tabiat, serta pembentukan sikap dan kepercayaan pada peserta didik. Guru sebagai perencana pembelajaran dituntut untuk mampu merancang pembelajaran dengan memanfaatkan berbagai jenis media dan sumber belajar yang sesuai agar proses pembelajaran berlangsung secara efektif dan efisien (Danim, 2010).

Seiring dengan perkembangan ilmu pengetahuan dan teknologi yang pesat, sudah seharusnya bagi seorang pendidik berani berpikir kreatif dalam mengembangkan metode dan media pembelajaran yang tepat pada proses pembelajaran di kelas. Tersedianya media penting sekali untuk merangsang kegiatan belajar siswa. Salah satu media pembelajaran yang perlu dikembangkan dan diterapkan dalam proses pembelajaran adalah media pembelajaran berbasis teknologi multimedia. Beberapa penelitian telah membuktikan bahwa pengembangan media pembelajaran berbasis multimedia dapat meningkatkan perhatian siswa dalam proses pembelajaran. Media pembelajaran dengan materi yang tepat, runtut dan disajikan lengkap sesuai dengan kompetensi yang diharapkan dan layak pakai akan sangat membantu dalam proses pembelajaran. Media pembelajaran yang mudah digunakan, lebih menarik, dan lebih informatif akan membuat minat siswa untuk mempelajari materi pun lebih meningkat sehingga lebih mudah memahami pelajaran yang telah dijelaskan oleh guru. Selain itu, dengan penggunaan media pembelajaran, keterbatasan tenaga pengajar juga bisa diatasi (Rahayuningsih, 2017). 
Salah satu aplikasi multimedia yang digunakan dalam pengembangan media pembelajaran adalah lectora inspire. Lectora inspire merupakan software multimedia yang dapat digunakan dalam pembuatan media pembelajaran interaktif dengan tampilan menarik, yang disertai dengan gambar, audio dan video singkat yang dapat mewakili penyampaian nilai-nilai dari materi yang disampaikan. Dalam penggunaannya, media lectora inspire adalah salah satu aplikasi perangkat lunak atau software aplication. Software tersebut memiliki keuntungan dalam bidang pendidikan antara lain, dengan teknologi ini bahan ajar dapat ditampilkan dalam berbagai animasi, dan dapat disimpan dalam bentuk CD sehingga siswa lebih fokus dalam pembelajaran dan memusatkan perhatiannya, media pembelajaran inipun dapat mengajarkan siswa belajar mandiri dan meningkatkan semangat dalam menerima pembelajaran dikarenakan fitur-fitur dan tools yang menarik serta menyerupai games yang menarik minat belajar siswa. Guru akan lebih mudah dalam memberikan pembelajaran di kelas, sehingga pembelajaranpun akan lebih efektif dan efisien. Penggunaan media pembelajaran berbasis multimedia dengan aplikasi lectora inspire telah dikembangkan oleh banyak peneliti dalam berbagai mata pelajaran.

Teknik pembelajaran yang monoton, yang menggunakan komunikasi secara verbal seperti metode ceramah menjadikan siswa merasa bosan, kurang memperhatikan pelajaran dan susah untuk diajak berkonsentrasi dalam belajar. Di sisi lain, teknologi komputer belum dimanfaatkan untuk proses pembelajaran, sehingga menyebabkan turunnya motivasi dan minat belajar siswa. Hal tersebut dikarenakan terbatasnya pengetahuan guru dalam mengembangkan media pembelajaran yang interaktif sebagai alat bantu dalam menyampaikan materi pelajaran.

Hasil observasi yang dilakukan pada Januari 2019 di SDN 197 Sapolohe, Kecamatan Bontobahari, Kabupaten Bulukumba ditemukan hambatan dalam pelaksanaan proses belajar mengajar, yaitu kurangnya pemanfaatan media pembelajaran yang mendukung. Belum adanya guru yang menggunakan komputer sebagai sarana belajar atau media pembelajaran. Guru masih menggunakan buku sebagai sumber belajar dan papan tulis sebagai media pembelajaran, khususnya pada mata pelajaran Ilmu Pengetahuan Sosial (IPS).
Hal ini menyebabkan siswa cenderung bersikap pasif dalam proses pembelajaran, sehingga hanya sebagai penerima informasi dari guru. Media pembelajaran cocok untuk diterapkan dalam semua mata pelajaran, termasuk mata pelajaran IPS di SD. Mata pelajaran IPS mempunyai materi yang kompleks dan terkadang sulit dibawa ke dalam pembelajaran sesuai dengan realita. Oleh karena itu, guru membutuhkan media pembelajaran yang dapat mempermudah penyampaian materi IPS kepada siswa. Materi IPS harus disampaikan semenarik mungkin dengan media pembelajaran yang bervariasi. Penggunaan media pembelajaran berbasis aplikasi lectora inspire dalam mata pelajaran IPS diharapkan dapat mempermudah siswa mempelajari materi IPS yang kompleks. Berdasarkan hal tersebut, Peneliti sangat tertarik melaksanakan penelitian dan pengembangan media pembelajaran berbasis aplikasi lectora inspire pada mata pelajaran IPS Kelas V di SDN 197 Sapolohe Kecamatan Bontobahari, Kabupaten Bulukumba.

\section{METODE PENELITIAN}

Penelitian ini merupakan penelitian pengembangan atau Research and Development yang bertujuan menghasilkan atau mengembangkan sebuah produk tertentu.

Prosedur penelitian yang dilakukan peneliti dalam pengembangan ini diadaptasi dari langkahlangkah pengembangan yang dikemukakan oleh Borg \& Gall dengan pembatasan. Borg \& Gall (dalam Emzir, 2013) menyatakan bahwa dimungkinkan untuk membatasi penelitian dalam skala kecil, termasuk membatasi langkah penelitian. Penerapan langkah-langkah pegembangannya disesuaikan dengan kebutuhan peneliti. Mengingat keterbatasan waktu dan dana yang dimiliki oleh peneliti, maka langkah-langkah tersebut disederhanakan menjadi 8 langkah pengembangan sebagai berikut:

1. Penelitian pendahuluan dan pengumpulan data

2. Perencanaan

3. Pengembangan draf produk

4. Uji validitas (uji ahli)

5. Revisi I

6. Uji kelompok kecil

7. Revisi II

8. Produk akhir

Penelitian ini menitik beratkan pada pengembangan produk media pembelajaran menggunakan aplikasi Lectora Inspire pada mata 
pelajaran IPS Kelas V di SDN 197 Sapolohe, Kecamatan Bontobahari, Kabupaten Bulukumba. Penelitian pengembangan ini sebatas pada uji kelayakan media pembelajaran, belum sampai pada uji keefektifan secara nyata dalam proses pembelajaran.

Adapun model penelitian dan pengembangan tersebut dapat disajikan dalam gambar berikut ini:

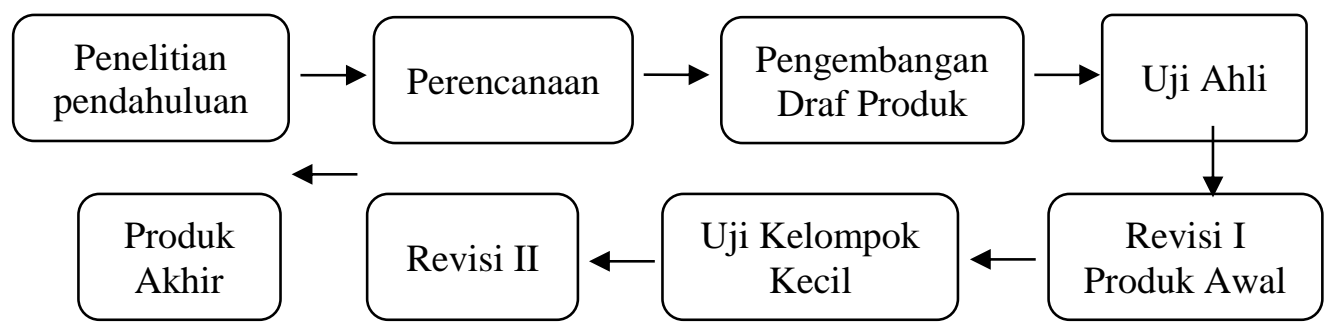

Gambar 1. Skema Prosedur Pengembangan

Teknik yang digunakan untuk mengumpulkan data adalah dengan menggunakan angket. Angket akan diberikan kepada ahli media, ahli materi, serta siswa untuk dapat memberikan penilaian mengenai produk yang sedang dikembangkan. Angket merupakan teknik pengumpulan data yang dilakukan dengan cara memberi seperangkat pertanyaan atau pernyataan kepada responden untuk dijawabnya (Sugiyono, 2012). Setiap responden memberikan penilaian terhadap media pembelajaran sesuai pendapat pribadi dari responden.

Pengujian validitas yang digunakan dalam penelitian ini adalah validitas konstruk (construct validity). Validitas konstruk berkenaan dengan konstruk atau struktur dan karakteristik psikologis aspek yang akan diukur dengan instrumen (Sukmadinata, 2009).

Teknik analisis data dilakukan menggunakan teknik analisis deskriptif kuantitatif. Teknik ini merupakan cara menganalisis data kuantitatif yang diperoleh dari angket uji ahli serta uji lapangan. Data kuantitatif yang diperoleh dari angket selanjutnya dikonversikan ke data kualitatif dengan skala 5 (skala likert) untuk mengetahui kualitas produk dengan uraian berikut:

Tabel 1: Pedoman Penilaian Skor

\begin{tabular}{lc}
\hline \multicolumn{1}{c}{ Data kualitatif } & Skor \\
\hline Sangat Baik (SB) & 5 \\
\hline Baik (B) & 4 \\
\hline Cukup Baik (CB) & 3 \\
\hline Kurang (K) & 2 \\
\hline Sangat Kurang (SK) & 1 \\
\hline
\end{tabular}

Konversi skala lima tersebut menggunakan acuan konversi pada Pendekatan Acuan Patokan (PAP) yang dikembangkan oleh Eko Putro Widoyoko (2009: 238) sebagaimana tabel di bawah ini:

Tabel 2: Konversi Nilai

\begin{tabular}{ccc}
\hline \multicolumn{2}{c}{ Skor } & \multirow{2}{*}{ Klasifikasi } \\
\cline { 1 - 2 } Rumus & Rerata Skor & \\
\hline $\bar{X}>\overline{X_{l}}+1,8 \mathrm{Sbi}$ & $\mathrm{X}>4,2$ & Sangat Baik \\
\hline$\overline{X_{l}}+0,6 \mathrm{Sbi}<\boldsymbol{X} \leq \overline{X_{l}}+1,8 \mathrm{Sbi}$ & $3,4<\mathrm{X} \leq 4,2$ & Baik \\
\hline$\overline{X_{l}}-0,6 \mathrm{Sbi}<\boldsymbol{X} \leq \overline{X_{l}}+0,6 \mathrm{Sbi}$ & $2,6<\mathrm{X} \leq 3,4$ & Cukup \\
\hline$\overline{X_{l}}-1,8 \mathrm{Sbi}<\boldsymbol{X} \leq \overline{X_{l}}-0,6 \mathrm{Sbi}$ & $1,8<\mathrm{X} \leq 2,6$ & Kurang \\
\hline $\boldsymbol{X} \leq \overline{X_{l}}-1,8 \mathrm{Sbi}$ & $\mathrm{X} \leq 1,8$ & Sangat Kurang \\
\hline
\end{tabular}

Sumber: Eko Putro Widoyoko (2009) 
Menghitung rata-rata tiap aspek dengan rumus berikut:

$$
\begin{aligned}
& \text { rata - rata tiap aspek } \\
& =\frac{\text { jumlah skor rata - rata tiap indikator }}{\text { jumlah indikator }}
\end{aligned}
$$

Dalam penelitian ini, ditetapkan nilai kelayakan produk minimal " 3,4 " dengan kategori "Baik", sehingga hasil penelitian, baik dari ahli materi, ahli media, dan siswa, jika telah didapat hasil penilaian akhir dengan nilai minimal, maka produk hasil pengembangan tersebut dianggap layak digunakan.

\section{HASIL DAN PEMBAHASAN}

\section{Gambaran Awal Kebutuhan Media Pembelajaran berbasis Aplikasi Lectora Inspire pada Mata Pelajaran IPS Kelas V}

Calon peneliti melakukan penelitian pendahuluan atau analisis kebutuhan untuk mengetahui kebutuhan subyek terhadap produk yang akan dikembangkan. Sehingga produk yang dihasilkan diharapkan benar-benar produk yang sesuai dengan kebutuhan siswa pada umumnya. Analisis kebutuhan ini dilakukan guna mendapatkan informasi mengenai kebutuhan siswa terkait penggunaan media pembelajaran dari mata pelajaran yang akan disajikan.

a. Analisis kebutuhan media pembelajaran

Dari hasil observasi yang dilakukan di SDN 197 Sapolohe, Kecamatan Bontobahari, Kabupaten Bulukumba tentang kebutuhan media untuk pembelajaran, didapatkan informasi bahwa pada pembelajaran khususnya pada mata pelajaran IPS hanya menggunakan media papan tulis sebagai alat untuk menyampaikan materi dan buku sebagai sumber informasi. Oleh sebab itu, siswa memerlukan media pembelajaran yang interaktif serta menarik guna menunjang penyampaian materi pada pembelajaran IPS. Selain itu guru mendukung pengembangan media pembelajaran berbasis aplikasi lectora inspire ini sebagai salah satu alternatif pendukung dalam proses pembelajaran di kelas V SDN 197 Sapolohe.

b. Analisis kebutuhan dan karakteristik siswa

Siswa SDN 197 Sapolohe, Kecamatan Bontobahari, Kabupaten Bulukumba cenderung bosan dengan penyampaian materi yang mengandalkan teks sebagai medianya. Siswa membutuhkan media yang lebih kompleks agar dapat menarik minat mereka untuk belajar. Media tersebut dapat berupa gabungan beberapa komponen media, diantaranya teks, gambar, animasi, suara, dan video.

\section{Gambaran Hasil Pengembangan Media Pembelajaran berbasis Aplikasi Lectora Inspire pada Mata Pelajaran IPS Kelas V}

a. Penelitian Pendahuluan dan Pengumpulan Data

Tahap tersebut dilakukan untuk mengetahui kebutuhan pembelajaran di lapangan. Peneliti melakukan penelitian pendahuluan untuk mengetahui kebutuhan subyek terhadap produk yang akan dikembangkan. Sehingga produk yang dihasilkan diharapkan benar-benar produk yang sesuai dengan kebutuhan siswa pada umumnya. Tahap pengumpulan data dilakukan guna mendapatkan informasi mengenai kebutuhan siswa terkait penggunaan media pembelajaran dari mata pelajaran yang akan disajikan. Tahap ini dilakukan dengan melakukan observasi di SDN 197 Sapolohe, Kecamatan Bontobahari, Kabupaten Bulukumba.

\section{b. Perencanaan}

Mengacu pada analisis kebutuhan maka didapatkan gambaran umum mengenai permasalahan yang dihadapi. Tahap perencanaan merupakan tindak lanjut dari analisis kebutuhan, perencanaan media pembelajaran berbasis aplikasi lectora inspire ini disesuaikan dengan analisis kebutuhan. Pada tahap ini ada berbagai macam kegiatan yang harus dilakukan antara lain sebagai berikut:

1) Penyusunan Materi

Materi yang disampaikan dalam produk media pembelajaran berbasis aplikasi lectora inspire pada mata pelajaran IPS kelas V adalah Karakteristik Geografis Indonesia yang diperoleh dari silabus yang digunakan di SDN 197 Sapolohe. Materi ini dikumpulkan oleh peneliti dari berbagai referensi buku dan hasil searching di internet.

\section{2) Pembuatan Flowchart}

Flowchart (bagan alir) adalah suatu bagan yang menggunakan lambang-lambang atau simbolsimbol tertentu yang menggambarkan urutan proses dalam suatu program. Flowchart digunakan untuk membantu perancangan media pembelajaran berbasis multimedia interaktif. Flowchart bermanfaat untuk menentukan alur program yang akan dibuat dalam pembelajaran.

3) Pembuatan Storyboard

Storyboard adalah kumpulan sketsa 
gambar yang disusun secara berurutan dan disesuaikan dengan penjelasannya sehingga maksud atau tujuan tersampaikan dengan mudah dan baik. Pembuatan storyboard dilakukan setelah pembuatan flowchart, karena flowchart digunakan sebagai acuan pembuatan storyboard. Pengembangan Draf Produk

Setelah tahap perencanaan maka peneliti melakukan tahap selanjutnya yaitu tahap pengembangan. Pengembang membuat rancangan media pembelajaran dari desain dan materi yang telah disediakan, serta bahan-bahan pendukung seperti audio, video, dan gambar pendukung yang telah dikumpulkan untuk dikembangkan menjadi media pembelajaran dengan menggunakan aplikasi Lectora Inspire.

c. Uji Ahli (Validasi ahli)

Setelah produk awal selesai, tahap selanjutnya adalah Uji Ahli. Pada penelitian pengembangan media pembelajaran berbasis aplikasi Lectora Inspire pada Mata Pelajaran IPS Kelas V ini, uji ahli dilakukan oleh 2 orang dosen PGSD FIP UNM yaitu Bapak Dr. Amir Pada, M.Pd sebagai ahli materi dan Bapak Bhakti Prima Findiaga Hermuttaqien, S.Pd., M.Pd sebagai ahli media, serta 1 orang guru kelas V (praktisi pembelajaran) yaitu Bapak Burhan, A.Ma.Pd.
Proses uji ahli ini dilakukan dengan cara memberikan atau memperlihatkan produk awal media pembelajaran berbasis aplikasi Lectora Inspire pada Mata Pelajaran IPS Kelas V beserta lembar validasinya kepada ketiga ahli uji. Kemudian, para ahli uji memberikan penilaian, komentar atau saran dalam lembar yang telah disediakan. Hasil analisis dari lembar validasi selanjutnya dijadikan bahan pertimbangan dan revisi perbaikan. Angket menggunakan skala likert dengan lima alternatif jawaban yaitu sangat baik (SB), baik (B), cukup baik (CB), sangat kurang (SK) dan kurang (K).

Adapun data hasil validasi media pembelajaran berbasis aplikasi Lectora Inspire pada Mata Pelajaran IPS Kelas V yaitu sebagai berikut:

1) Penilaian Ahli Materi

Setelah media pembelajaran selesai dibuat, dilakukan validasi ahli materi. Validasi ahli materi diperlukan untuk menilai materi yang telah disusun dalam media pembelajaran berbasis aplikasi Lectora Inspire pada Mata Pelajaran IPS dengan Pokok Materi Karakteristik Geografis Indonesia. Hasil dan analisis validasi dari ahli materi dapat dilihat pada tabel berikut:

Tabel 3: Hasil Validasi Ahli Materi

\begin{tabular}{|c|c|c|}
\hline Aspek yang dinilai & $\begin{array}{c}\text { Skor } \\
\text { Penilaian }\end{array}$ & Kategori \\
\hline 1. Kesesuaian materi dengan KI dan KD & 5 & Sangat Baik \\
\hline 2. Keaktualan isi materi & 5 & Sangat Baik \\
\hline 3. Konsep dalam materi sudah benar & 4 & Baik \\
\hline 4. Materi yang disampaikan sudah lengkap & 4 & Baik \\
\hline $\begin{array}{l}\text { 5. Gambar yang disajikan sebagai contoh sesuai dengan materi yang } \\
\text { disampaikan }\end{array}$ & 5 & Sangat Baik \\
\hline $\begin{array}{l}\text { 6. Materi mudah dipahami karena didukung dengan bagan, gambar } \\
\text { dan petunjuk yang jelas }\end{array}$ & 4 & Baik \\
\hline 7. Bahasa yang digunakan mudah dipahami & 5 & Sangat Baik \\
\hline 8. Tata bahasa, ejaan, dan istilah yang digunakan sudah tepat & 5 & Sangat Baik \\
\hline 9. Materi merangsang siswa berpikir lebih runtut & 4 & Baik \\
\hline 10. Gambar dengan teks saling mendukung & 4 & Baik \\
\hline 11. Indikator pembelajaran yang ingin dicapai sudah jelas & 5 & Sangat Baik \\
\hline 12. Materi dapat digunakan siswa untuk belajar secara mandiri & 4 & Baik \\
\hline 13. Materi yang disajikan menarik bagi siswa & 4 & Baik \\
\hline 14 Penyajian materi sistematis dan logis & 4 & Baik \\
\hline 15. Pemberian contoh dapat menarik siswa untuk belajar & 4 & Baik \\
\hline 16. Video relevan dan terpadu dengan materi & 4 & Baik \\
\hline 17. Penyampaian materi dapat meningkatkan kemandirian siswa dalam & 4 & Baik \\
\hline
\end{tabular}


belajar

18. Penyampaian soal evaluasi sesuai dengan materi yang diajarkan

19. Jenis soal evaluasi sesuai dengan tema materi yang disampaikan

20. Pemberian umpan balik soal evaluasi

Jumlah

Rata-rata

Klasifikasi

\begin{tabular}{cc}
4 & Baik \\
\hline 5 & Sangat Baik \\
\hline 4 & Baik \\
\hline \multicolumn{2}{c}{4,35} \\
\multicolumn{2}{c}{ Sangat Baik }
\end{tabular}

Berdasarkan tabel di atas terdapat 20 butir indikator/aspek yang dinilai. Jumlah skor validasi oleh ahli materi adalah 87 , sehingga rerata hasil penilaian dari ahli materi adalah 4,35. Mengacu pada tabel konversi, maka hasil penilaian dari ahli materi adalah sangat baik. Oleh karena itu dapat disimpulkan bahwa media pembelajaran berbasis aplikasi Lectora Inspire yang dikembangkan oleh peneliti ditinjau dari aspek materi yang disajikan Layak digunakan untuk uji coba produk.
2) Penilaian Ahli Media

Validasi yang dilakukan oleh ahli media digunakan untuk menilai produk media pembelajaran berbasis aplikasi Lectora Inspire. Penilaian ini bermaksud melihat layak atau tidak media tersebut untuk di implementasikan kepada siswa. Hasil dan analisis dari validasi ahli media dapat dilihat dalam tabel berikut:

IPS sebelum dan sesudah diberikan perlakuan model pembelajaran kooperatif tipe Make a Match sebagai berikut:

Tabel 4: Hasil Validasi Ahli Media

\begin{tabular}{|c|c|c|c|}
\hline No. & Aspek yang dinilai & $\begin{array}{c}\text { Skor } \\
\text { Penilaian }\end{array}$ & Kategori \\
\hline 1. & $\begin{array}{l}\text { Ketercakupan materi dalam media } \\
\text { pembelajaran yang akan dicapai. }\end{array}$ & 4 & Baik \\
\hline 2. & $\begin{array}{l}\text { Istilah yang digunakan sesuai dengan situasi siswa (mudah } \\
\text { dipahami) }\end{array}$ & 4 & Baik \\
\hline 3. & Struktur penggunaan kalimat jelas & 4 & Baik \\
\hline 4. & Sebagai alternative metode/strategi pembelajaran & 4 & Baik \\
\hline 5. & Memberi kejelasan tentang materi & 3 & Cukup Baik \\
\hline 6. & Menarik minat atau perhatian untuk belajar & 4 & Baik \\
\hline 7. & Kesesuaian dengan tingkat perkembangan intelektual siswa & 4 & Baik \\
\hline 8. & Meningkatkan belajar mandiri siswa & 5 & Sangat Baik \\
\hline 9. & Konsep soal evaluasi sesuai dengan materi yang disampaikan & 4 & Baik \\
\hline 10. & Kualitas umpan balik soal evaluasi & 3 & Cukup Baik \\
\hline 11. & Desain layout soal evaluasi menarik siswa untuk belajar & 3 & Cukup Baik \\
\hline 12. & $\begin{array}{l}\text { Kemudahan siswa dan guru untuk menggunakan media } \\
\text { pembelajaran }\end{array}$ & 3 & Cukup Baik \\
\hline 13. & Pemilihan tipe, ukuran dan warna huruf & 4 & Baik \\
\hline 14 & Kekontrasan warna background media dengan objek di depannya & 4 & Baik \\
\hline 15. & Kualitas gambar dan video yang disajikan & 4 & Baik \\
\hline & Pengaturan tata letak tampilan & 4 & Baik \\
\hline & Kejelasan navigasi atau petunjuk alur penggunaan media & 3 & Cukup Baik \\
\hline & Konsistensi navigasi & 4 & Baik \\
\hline & Komunikatif & 4 & Baik \\
\hline 20. & Interaktif & 4 & Baik \\
\hline & Jumlah & \multicolumn{2}{|c|}{76} \\
\hline & Rata-rata & \multicolumn{2}{|c|}{3,8} \\
\hline & Klasifikasi & \multicolumn{2}{|c|}{ Baik } \\
\hline
\end{tabular}


Jumlah skor validasi dari ahli media adalah 76 dari 20 indikator/aspek yang dinilai, sehingga rerata hasil penilaian ahli media adalah 3,8 . Mengacu pada tabel konversi, maka penilaian dari ahli media adalah baik. Oleh karena itu dapat disimpulkan bahwa media pembelajaran berbasis aplikasi Lectora Inspire yang dikembangkan oleh peneliti ditinjau dari aspek media yang disajikan Layak digunakan untuk uji coba produk.

3) Penilaian Praktisi Pembelajaran (Guru Kelas V)

Tabel 5: Hasil Validasi Praktisi Pembelajaran (Guru)

\begin{tabular}{|c|c|c|c|}
\hline No & Aspek yang dinilai & $\begin{array}{c}\text { Skor } \\
\text { Penilaian }\end{array}$ & Kategori \\
\hline 1. & Kesesuaian materi dengan KI dan KD & 5 & Sangat Baik \\
\hline 2. & Keaktualan isi materi & 4 & Baik \\
\hline 3. & Konsep dalam materi sudah benar & 4 & Baik \\
\hline & Materi yang disampaikan sudah lengkap & 4 & Baik \\
\hline 5. & $\begin{array}{l}\text { Gambar yang disajikan sebagai contoh sesuai dengan materi yang } \\
\text { disampaikan }\end{array}$ & 5 & Sangat Baik \\
\hline & $\begin{array}{l}\text { Materi mudah dipahami karena didukung dengan bagan, gambar } \\
\text { dan petunjuk yang jelas }\end{array}$ & 5 & Sangat Baik \\
\hline & Bahasa yang digunakan mudah dipahami & 4 & Baik \\
\hline & Tata bahasa, ejaan, dan istilah yang digunakan sudah tepat & 4 & Baik \\
\hline & Materi merangsang siswa berpikir lebih runtut & 5 & Sangat Baik \\
\hline & Gambar dengan teks saling mendukung & 5 & Sangat Baik \\
\hline & Indikator pembelajaran yang ingin dicapai sudah jelas & 5 & Sangat Baik \\
\hline & Materi dapat digunakan siswa untuk belajar secara mandiri & 5 & Sangat Baik \\
\hline & Materi yang disajikan menarik bagi siswa & 5 & Sangat Baik \\
\hline & Penyajian materi sistematis dan logis & 4 & Baik \\
\hline & Pemberian contoh dapat menarik siswa untuk belajar & 5 & Sangat Baik \\
\hline & Video relevan dan terpadu dengan materi & 4 & Baik \\
\hline & $\begin{array}{l}\text { Penyampaian materi dapat meningkatkan kemandirian siswa dalam } \\
\text { belajar }\end{array}$ & 4 & Baik \\
\hline & Penyampaian soal evaluasi sesuai dengan materi yang diajarkan & 5 & Sangat Baik \\
\hline & Jenis soal evaluasi sesuai dengan tema materi yang disampaikan & 5 & Sangat Baik \\
\hline & Pemberian umpan balik soal evaluasi & 4 & Baik \\
\hline & Jumlah & \multicolumn{2}{|c|}{91} \\
\hline & Rata-rata & \multicolumn{2}{|c|}{4,55} \\
\hline & Klasifikasi & \multicolumn{2}{|c|}{ Sangat Baik } \\
\hline
\end{tabular}

Berdasarkan tabel di atas terdapat 20 butir indikator/aspek yang dinilai. Jumlah skor validasi oleh praktisi pembelajaran (guru) adalah 91, sehingga rerata hasil penilaian dari ahli materi adalah 4,55. Mengacu pada tabel konversi, media pembelajaran berbasis aplikasi Lectora Inspire pada Mata Pelajaran IPS menurut tanggapan guru kelas V adalah sangat baik.

4) Komentar atau Saran

Adapun komentar atau saran para ahli uji, yaitu sebagai berikut: a) Ahli Materi

(1)Lengkapi kalimat pada indikator 2 dan 4 sesuai masukan, agar lebih jelas/terarah.

(2) Tambahkan video tentang pengaruh positif/keuntungan letak geografis Indonesia.

b) Ahli Media

(1)Dalam layer Evaluasi multiple choice dan benar salah sebaiknya satu layer satu soal, serta di akhir sebaiknya ada skor siswa

(2) Sebaiknya tombolnya ada suaranya untuk mempermudah siswa dalam mengakses.

(3) Sebaiknya videonya disesuaikan setting suaranya. 
(4) Sebaiknya gunakan gambar yang menarik dengan penjelasan yang singkat, padat dan jelas.

(5) Berilah penjelasan tambahan pada petunjuk penggunaan ditiap buttonnya karena anak SD terkadang multitafsir.

(6) Perhatikan kalimat yang anda gunakan pada penyampaian materi sebaiknya gunakan kalimat interaktif.

\section{d. Revisi I}

Berdasarkan komentar dan saran ahli materi dan ahli media maka dilakukan revisi terhadap media pembelajaran yang dikembangkan peneliti. Berikut ini beberapa tampilan yang dilakukan revisi dan perbaikan:

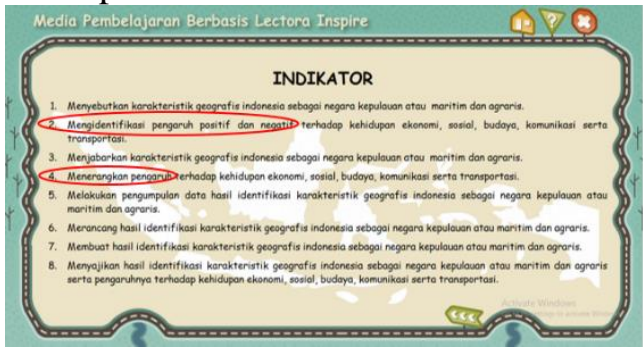

Gambar 2. Tampilan Indikator sebelum Revisi

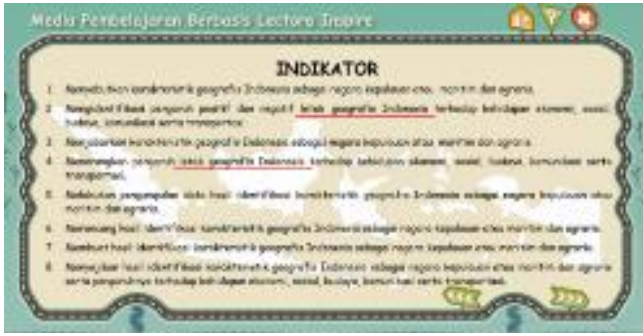

Gambar 3. Tampilan Indikator setelah Revisi

Berdasarkan saran dari ahli materi, pada indikator point ke 2 dan ke 4 ditambahkan kalimat "letak geografis Indonesia" setelah kata pengaruh agar lebih jelas atau terarah.

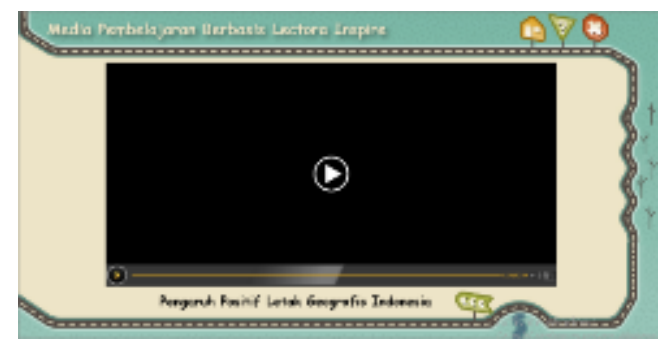

Gambar 4. Tampilan Slide Video Pengaruh Positif Letak Geografis Indonesia

Pada produk awal media pembelajaran yang dikembangkan oleh peneliti, hanya terdapat dua video pembelajaran yaitu tentang Letak Geografis
Indonesia dan pengaruhnya, serta Perubahan musim di Indonesia. Berdasarkan saran dari ahli materi, video tentang pengaruh positif (keuntungan) letak geografis Indonesia ditambahkan pada media pembelajaran, agar siswa bisa lebih mudah memahami pengaruh positif letak geografis Indonesia.

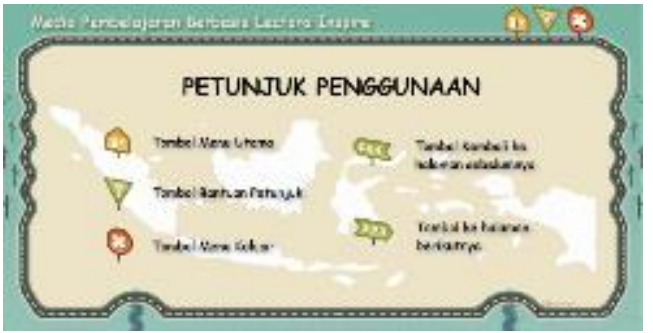

Gambar 5. Tampilan Menu Petunjuk sebelum Revisi

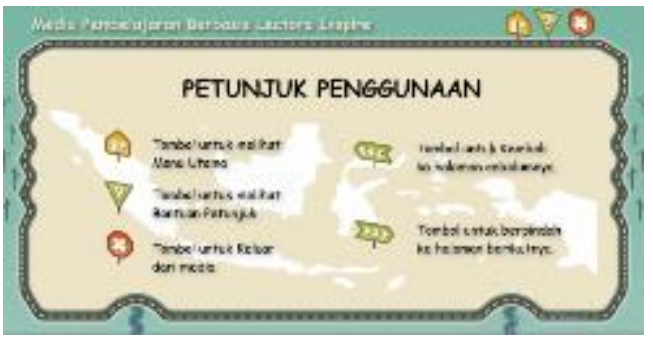

Gambar 6. Tampilan Menu Petunjuk setelah Revisi

Berdasarkan saran dari ahli media, pengembang memberikan penjelasan tambahan pada petunjuk penggunaan di setiap buttonnya, agar siswa (penggunanya) lebih mudah memahami dan tidak bingung dalam mengoperasikan media.

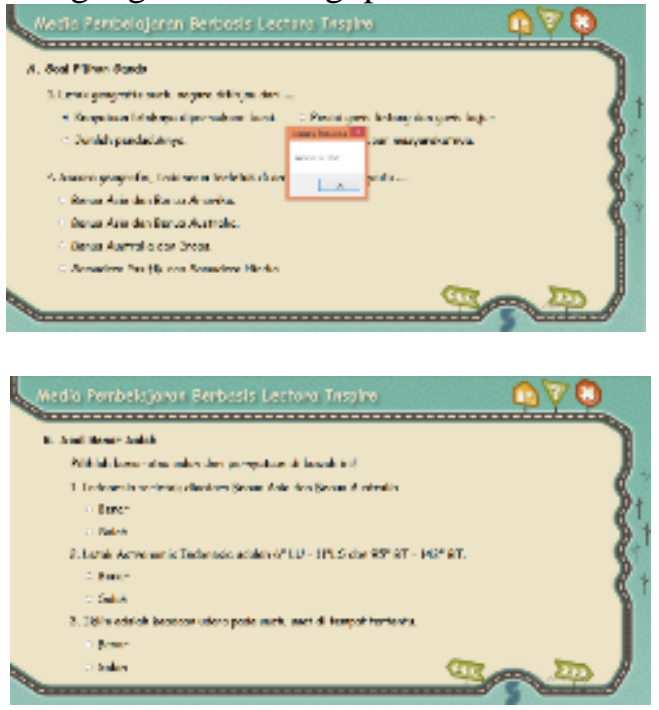

Gambar 7. Tampilan Soal Evaluasi sebelum Revisi

Pada produk awal media pembelajaran yang dikembangkan oleh peneliti, bagian soal multiple 
choice dan benar salah terdapat dua hingga tiga soal dalam setiap layer. Selain itu, feedback yang diberikan setelah menjawab soal hanya berupa kata-kata motivasi.
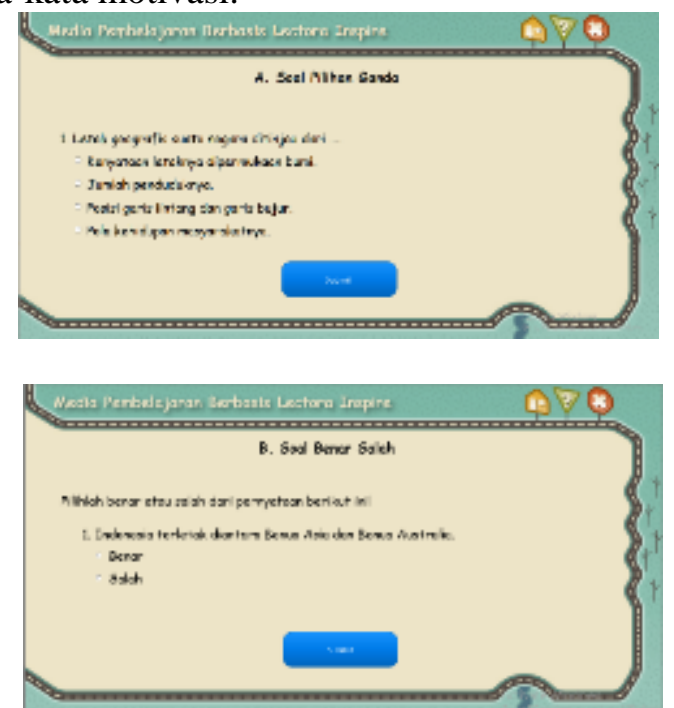

Gambar 8. Tampilan Soal Evaluasi setelah Revisi
Berdasarkan saran dari ahli media, tampilan soal evaluasi multiple choice dan soal benar salah yang awalnya dalam satu layer terdapat dua hingga tiga soal, diubah menjadi masing-masing 1 soal di setiap layernya. Selain itu, di akhir setelah siswa menjawab soal multiple choice dan soal benar salah diberikan skor pencapaian siswa.

Pengembang juga telah menambahkan suara klik pada setiap tombol yang ada untuk memudahkan pengguna dalam mengakses media pembelajaran. Pada saat penyampaian materi menggunakan media pembelajaran berbasis aplikasi Lectora Inspire ini, pengembang juga telah menggunakan kalimat interaktif untuk lebih memudahkan siswa dalam memahami materi dan menarik perhatian siswa sehingga lebih aktif dan tidak bosan selama proses pembelajaran berlangsung.

e. Uji Coba Kelompok Kecil

Uji coba produk melibatkan 10 siswa, yang masing-masing 5 siswa perwakilan dari kelas VA dan VB di SDN 197 Sapolohe. Adapun hasil uji coba produk sebagai berikut:

Tabel 6: Hasil Uji Coba Kelompok Kecil

\begin{tabular}{|c|c|c|c|c|}
\hline No. & Aspek yang dinilai & $\begin{array}{c}\text { Skor } \\
\text { Penilaian }\end{array}$ & Rata-rata & Kategori \\
\hline 1. & $\begin{array}{l}\text { Saya senang belajar menggunakan media pembelajaran } \\
\text { lectora inspire }\end{array}$ & 47 & 4,7 & $\begin{array}{l}\text { Sangat } \\
\text { Baik }\end{array}$ \\
\hline 2. & $\begin{array}{l}\text { Materi mudah dipahami karena didukung dengan gambar } \\
\text { dan petunjuk yang jelas }\end{array}$ & 45 & 4,5 & $\begin{array}{l}\text { Sangat } \\
\text { Baik }\end{array}$ \\
\hline 3. & $\begin{array}{l}\text { Saya lebih semangat belajar menggunakan media } \\
\text { pembelajaran lectora inspire }\end{array}$ & 44 & 4,4 & $\begin{array}{l}\text { Sangat } \\
\text { Baik }\end{array}$ \\
\hline 4. & Saya mudah mengerti materi dalam media & 47 & 4,7 & $\begin{array}{l}\text { Sangat } \\
\text { Baik }\end{array}$ \\
\hline 5. & Kalimat yang digunakan dalam media jelas & 45 & 4,5 & $\begin{array}{l}\text { Sangat } \\
\text { Baik }\end{array}$ \\
\hline 6. & $\begin{array}{l}\text { Gambar yang disajikan sebagai contoh sesuai dengan } \\
\text { materi yang disampaikan }\end{array}$ & 48 & 4,8 & $\begin{array}{l}\text { Sangat } \\
\text { Baik }\end{array}$ \\
\hline 7. & Cara penyampaian materi bagus & 41 & 4,1 & $\begin{array}{l}\text { Sangat } \\
\text { Baik }\end{array}$ \\
\hline 8. & Saya suka tampilan media pembelajaran lectora inspire & 46 & 4,6 & $\begin{array}{l}\text { Sangat } \\
\text { Baik }\end{array}$ \\
\hline 9. & Penempatan teks dan gambar dalam materi sudah seimbang & 43 & 4,3 & $\begin{array}{l}\text { Sangat } \\
\text { Baik }\end{array}$ \\
\hline 10. & $\begin{array}{l}\text { Saya suka jenis huruf yang digunakan dalam media } \\
\text { pembelajaran lectora inspire }\end{array}$ & 45 & 4,5 & $\begin{array}{l}\text { Sangat } \\
\text { Baik }\end{array}$ \\
\hline & $\begin{array}{l}\text { Saya suka warna tampilan media pembelajaran lectora } \\
\text { inspire }\end{array}$ & 47 & 4,7 & $\begin{array}{l}\text { Sangat } \\
\text { Baik }\end{array}$ \\
\hline
\end{tabular}




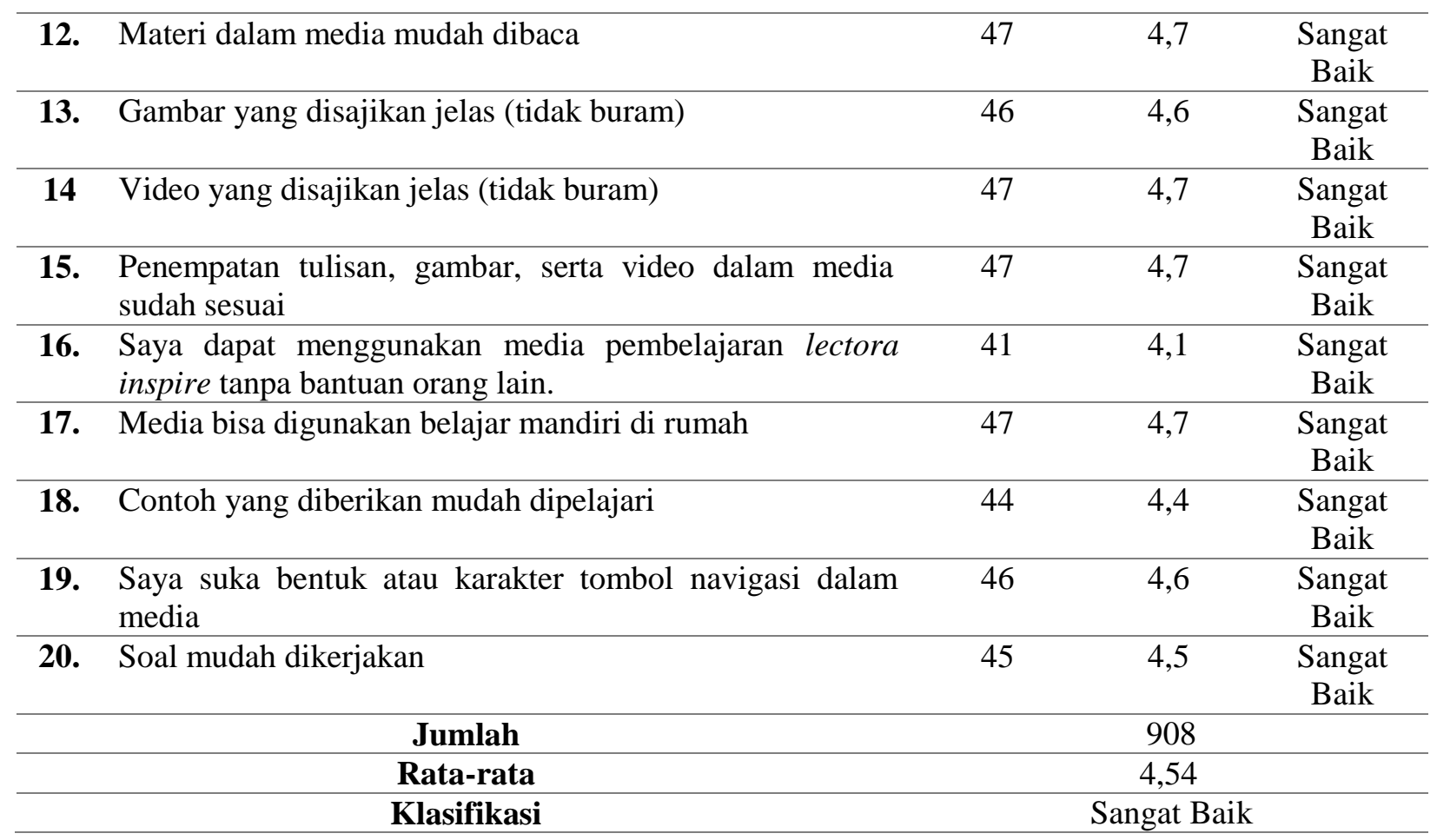

Jumlah skor penilaian berdasarkan data uji coba produk dalam kelompok kecil yang melibatkan 10 siswa dengan 20 indikator/aspek yang dinilai adalah 908 sehingga memperoleh rerata hasil penilaian sebesar 4,54. Mengacu pada tabel konversi, media pembelajaran berbasis aplikasi Lectora Inspire pada Mata Pelajaran IPS menurut tanggapan siswa Kelas $\mathrm{V}$ adalah sangat baik.

f. Revisi II dan Produk Akhir

Pada tahap revisi kedua ini, dilakukan dengan berdasar pada data hasil uji coba kelompok kecil terhadap 10 siswa responden yang kemudian dianalisis dan dijadikan bahan revisi produk akhir. Selanjutnya, dari data hasil uji coba kelompok kecil menunjukkan hasil bahwa media pembelajaran berbasis aplikasi Lectora Inspire pada Mata Pelajaran IPS Kelas V sudah sangat baik dan sangat layak sehingga dipandang tidak perlu revisi lagi. Olehnya itu, revisi kedua ini menjadi produk akhir media pembelajaran berbasis aplikasi Lectora Inspire pada Mata Pelajaran IPS Kelas V di SDN 197 Sapolohe.

\section{Tingkat Kelayakan Media Pembelajaran berbasis Aplikasi Lectora Inspire pada Mata Pelajaran IPS Kelas V}

Tingkat kelayakan media pembelajaran berbasis aplikasi Lectora Inspire pada mata pelajaran IPS Kelas V diperoleh dari hasil penilaian ahli materi, ahli media, praktisi pembelajaran (guru) dan siswa. Hasil validasi ahli materi media pembelajaran berbasis aplikasi lectora inspire ini memperoleh rerata skor 4,35. Mengacu pada tabel konversi, rerata skor uji ahli materi masuk dalam rentang $\mathrm{X}>4,2$ dengan kategori sangat baik. Hasil validasi ahli media memperoleh rerata skor 3,8. Mengacu pada tabel konversi, rerata skor uji ahli media masuk dalam rentang 3,4 $<X \leq 4,2$ dengan kategori baik. Hasil validasi dari praktisi pembelajaran (guru) memperoleh rerata skor 4,55. Mengacu pada tabel konversi, rerata skor uji ahli materi masuk dalam rentang $X>4,2$ dengan kategori sangat baik. Adapun hasil penilaian siswa berdasarkan data uji coba kelompok kecil memperoleh rerata skor 4,54. Mengacu pada tabel konversi, rerata skor uji coba kelompok kecil masuk dalam rentang $\mathrm{X}>4,2$ dengan kategori sangat baik.

Berdasarkan rerata skor hasil penilaian yang dilakukan oleh tiga validator dan siswa, diperoleh rerata skor sebesar 4,31 dengan kategori sangat baik. Oleh karena itu bisa disimpulkan bahwa media pembelajaran berbasis aplikasi Lectora Inspire ini sudah sangat layak untuk digunakan dalam proses pembelajaran. 
Pengembangan media pembelajaran berbasis aplikasi Lectora Inspire ini pada dasarnya bertujuan untuk memudahkan siswa dan guru dalam proses pembelajaran. Bagi siswa, media pembelajaran berbasis aplikasi Lectora Inspire ini bertujuan untuk memberikan pengetahuan dan pemahaman siswa, serta untuk menarik perhatian siswa dan meningkatkan motivasi belajar siswa. Sedangkan bagi guru, media pembelajaran ini bertujuan untuk dijadikan media penunjang dalam menyampaikan materi, dan mendorong kreativitas pendidik dalam membuat atau mengembangkan media pembelajaran.

Model penelitian pengembangan yang digunakan dalam penelitian ini, yaitu model yang dikemukakan oleh borg and gall, karena dianggap paling sesuai dengan penelitian ini. Namun, dalam penelitian ini model tersebut dimodifikasi, sehingga hanya sampai pada tahap ke delapan karena disebabkan oleh keterbatasan waktu dan biaya. Adapun tahap penelitian yang digunakan yaitu (1) Penelitian Pendahuluan dan Pengumpulan Data; (2) Perencanaan; (3) Pengembangan draf produk; (4) Uji validitas (uji ahli); (5) Revisi I; (6) Uji kelompok kecil; (7) Revisi II, dan (8) Produk akhir.

Pengembangan media pembelajaran berbasis aplikasi Lectora Inspire ini, diawali dengan tahap analisis kebutuhan atau pengumpulan informasi awal mengenai permasalahan umum di SDN 197 Sapolohe. Berdasarkan hasil analisis kebutuhan tersebut, peneliti kemudian memberikan solusi dengan mengembangkan sebuah media pembelajaran interaktif berbasis aplikasi Lectora Inspire. Proses pembuatan media pembelajaran dilaksanakan secara bertahap dari perencanaan hingga pengembangan produk media, dan dilakukan validasi ahli materi, validasi ahli media, praktisi pembelajaran (guru) dan uji coba kelompok kecil. Semua rangkaian tersebut dimaksudkan untuk memperoleh data yang selanjutnya dilakukan revisi atau perbaikan agar tercapai media pembelajaran yang layak dan bermanfaat bagi penggunanya.

Hasil validasi ahli materi media pembelajaran berbasis aplikasi lectora inspire ini memperoleh rerata skor 4,35. Mengacu pada tabel konversi, rerata skor uji ahli materi masuk dalam rentang $X>4,2$ dengan kategori sangat baik. Hasil validasi ahli media memperoleh rerata skor 3,8 . Mengacu pada tabel konversi, rerata skor uji ahli media masuk dalam rentang $3,4<X \leq 4,2$ dengan kategori baik. Hasil validasi dari praktisi pembelajaran (guru) memperoleh rerata skor 4,55. Mengacu pada tabel konversi, rerata skor uji ahli materi masuk dalam rentang $\mathrm{X}>4,2$ dengan kategori sangat baik.

Berdasarkan hasil uji coba ahli yang dilakukan oleh tiga validator, diperoleh hasil bahwa media pembelajaran berbasis aplikasi Lectora Inspire ini sudah layak untuk digunakan. Namun demikian, validator tetap memberikan saran atau masukan terhadap media pembelajaran berbasis aplikasi Lectora Inspire ini sehingga dilakukan perbaikan pada tahap Revisi I. Setelah tahap revisi I selesai, maka produk yang dihasilkan selanjutnya diujikan pada tahap uji coba kelompok kecil yang melibatkan 10 siswa Kelas V SDN 197 Sapolohe. Jumlah skor penilaian berdasarkan data uji coba kelompok kecil adalah 908 dengan rerata penilaian 4,54. Mengacu pada tabel konversi, rerata skor uji coba kelompok kecil masuk dalam rentang $X>4,2$ dengan kategori sangat baik.

Uji coba kelompok ini bertujuan untuk mengetahui kelayakan media pembelajaran berbasis aplikasi Lectora Inspire ini. Hasil uji coba ini menunjukkan bahwa media pembelajaran berbasis aplikasi Lectora Inspire sudah menarik dan membantu meningkatkan antusias dan semangat belajar siswa.

Berdasarkan hasil uji coba kelompok kecil, maka dilakukan revisi ke II terhadap media pembelajaran berbasis aplikasi Lectora Inspire. Hasil dari revisi II kemudian menjadi produk akhir media pembelajaran berbasis aplikasi Lectora Inspire pada Mata Pelajaran IPS Kelas V di SDN 197 Sapolohe Kecamatan Bontobahari, Kabupaten Bulukumba.

\section{SIMPULAN DAN SARAN}

Berdasarkan hasil penelitian dan pembahasan, maka dapat disimpulkan bahwa gambaran kebutuhan media pembelajaran yang telah dilakukan di SDN 197 Sapolohe melalui observasi, menunjukkan hasil bahwa pada pembelajaran khususnya pada mata pelajaran IPS siswa cenderung bosan karena guru hanya menggunakan media papan tulis sebagai alat untuk menyampaikan materi dan buku sebagai sumber informasi. Siswa membutuhkan media yang lebih kompleks agar dapat menarik minat mereka untuk belajar. Media tersebut dapat berupa gabungan 
beberapa komponen media, diantaranya teks, gambar, animasi, suara, dan video. Oleh sebab itu, siswa memerlukan media pembelajaran yang interaktif serta menarik guna menunjang penyampaian materi pada pembelajaran IPS.

Proses pengembangan media

pembelajaran berbasis aplikasi Lectora Inspire pada mata pelajaran IPS melalui 8 tahap, yaitu Penelitian pendahuluan dan pengumpulan data, Perencanaan, Pengembangan produk, Uji validitas (uji ahli), Revisi I, Uji kelompok kecil, Revisi II, dan Produk akhir.

Tingkat kelayakan media pembelajaran berbasis aplikasi Lectora Inspire pada mata pelajaran IPS berdasarkan penilaian ahli materi sebesar 4,35, ahli media sebesar 3,8, praktisi pembelajaran (guru) sebesar 4,55 dan siswa sebesar 4,54 sehingga memperoleh rerata skor sebesar 4,31 dengan kategori sangat baik yang menunjukkan hasil bahwa media pembelajaran tersebut layak untuk digunakan dalam proses pembelajaran bagi siswa Kelas V SDN 197 Sapolohe, Kecamatan Bontobahari, Kabupaten Bulukumba.

Adapun beberapa saran dalam penelitian ini yaitu sebaiknya guru mampu mengembangkan media pembelajaran menggunakan program Lectora Inspire agar proses pembelajaran lebih menarik. Setiap siswa sebaiknya memiliki produk media pembelajaran yang dikembangkan oleh peneliti ini secara mandiri, agar memperoleh manfaat dan pemahaman yang optimal. Hendaknya implementasi tidak dilakukan pada satu sekolah saja, sehingga dapat melihat kebermanfaatan media pada sekolah lain. Diharapkan pengembangan media pembelajaran selanjutnya tidak hanya sampai tahap uji kelayakan saja, hendaknya sampai pada uji keefektifan media pembelajaran dalam proses pembelajaran.

\section{DAFTAR RUJUKAN}

Arikunto, S. 2010. Prosedur Penelitian Suatu Pendekatan Praktik. Jakarta: PT. Rineka Cipta.

Danim, Sudarwan. 2010. Profesionalisasi dan Etika Profesi Guru. Bandung: Alfabeta.

Emzir. 2013. Metodologi Penelitian Pendidikan. Depok: PT. Raja Grafindo Persada.

Khanifatul. 2013. Pembelajaran Inovatif. Jogjakarta: Ar-Ruzz Media.

Prastowo, Andi. 2011. Panduan Kreatif Membuat Bahan Ajar Inovatif. Yogyakarta: Diva
Press.

Rahayuningsih, Puji. 2017. Aplikasi Media Pembelajaran Tajwid Berbasis Multimedia Bagi Siswa Sekolah Dasar. SimkiTechsain, 1(5) 2017. Universitas Nusantara PGRI Kediri.

Sukmadinata N.S. 2009. Metode Penelitian Pendidikan. Bandung: Remaja Rosdakarya. Sugiyono. 2012. Metode Penelitian Pendidikan. Bandung: CV. Alfabeta.

Widoyoko, E.P. 2009. Evaluasi Program Pembelajaran (Panduan Praktis bagi Pendidik dan Calon Pendidik. Yogyakarta: Pustaka Pelajar. 